\title{
Seyyahların Piri Evliyâ Çelebi: Seyahat mı? Şefaat mı?
}

\section{Master of Travelers Evliyâ Çelebi: Travel or Intercession?}

\section{Selim Hilmi ÖZKAN}

Sosyal Bilimler ve Türkçe Eğitimi Bölümü, YTU, İstanbul, Türkiye

\section{Özet}

Evliya Çelebi dünya üzerinde gelmiş geçmiş en önemli seyyahlardan birisidir. Gezmek ve yeni yerler görmek onun en önemli hasletlerinden birisidir. Evliya Çelebi gezip gördüğü yerleri sadece yalın bir anlatım ile anlatmayıp bir tarihçi, sosyolog ve edebiyatçı olarak kaleme almıştır. Aynı zamanda seyahatleri sırasında katıldığı kervanları ve kafileleri şenlendirmiştir. Aslında o dönemin şartlarında uzun geçen seyahatlerin vazgeçilmezlerinden birisidir. Bu çalışmada Evliya Çelebi'nin seyahate başlama serüveni ile birlikte gezdiğiv e gördüğü yerlere bakışı tarihi bir çerçevede kaleme alınacaktır.

Anahtar Kelimeler: Evliya Çelebi, Osmanlı Devleti, Seyahat, Seyyah

\section{Abstract}

Evliya Celebi was one of the most prominent travelers of all time. Traveling and seeing new places were ones of his most important inborn characteristics. Evliya Celebi did not only describe the places he had journeyed and seen in plain words but also described those journeys from the perspective of a historian, sociologist and a littérateur. Moreover, he vivified the convoys and caravans he joined in. In fact, he was one of the essential members of those journeys, which took much longer in the conditions of those times. In this work, the adventures of how the journey of Evliya Celebi had started and the places he had seen and journeyed have been written within a historical framework.

Key Words: Evliya Çelebi, Ottomen Empire, Travel, Travelers 


\section{Giriş Yerine...}

Gezmek ve yeni yerler görmek, insanoğlunun var olduğu günden bugüne yaptığı en önemli uğraşı alanlarından biri olmuştur. Bu durum insanoğlunun yaşadığ1 coğrafya ile yetinmemesinin veya başka yerleri merak etme duygusunun bir tezahürüdür. Burada kısa da olsa Evliya Çelebi'nin deyimi ile bir darb-1 mesel zikretmek istiyorum. Eğer "Cenab-1 Hak insanoğluna ey kulum bu dünya senin dese, o kul, şöyle gökyüzüne bir baktığı zaman, Ey Allah'ım şu gökyüzünü de versen olmaz mı acaba?" dermiş. Bunu nasıl yorumlarsanız yorumlayın. Buradan hareketle insanoğlu yakın çevresinden başlamak üzere hep yeni yerleri görmek için çeşitli seyahatler gerçekleştirmiştir. Bu seyahatler bazen ekonomik, bazen siyasi, bazen zorunlu sebeplerden, bazen dinî sebeplerden, bazen de sadece meraktan olmuştur. Bu seyahatlerin ferdî, gruplar hâlinde hatta tüm bir ordu ile de gerçekleştiği olmuştur. Milattan önce Makedonyalı İskender'i ta Mekodonya'dan kalkıp tüm Asya'yı bir baştan başa geçip Hindistan'a oradan Mısır'a sürükleyen sebep zannedersem yukarıda saydığımız gerekçelerden biridir. Yine Hun Türklerini Avrupa içlerine kadar sürükleyen bu gerekçeler olsa gerek. Cengiz'in ordularının Anadolu içlerine kadar gelmesi, Orta Asya'dan kalkan Oğuz Türklerinin önce Anadolu daha sonra Avrupa içlerine kadar gitmeleri siyasi, ekonomik, dinî gerekçelerle olduğu kadar yeni yerler keşfetme duygusunun da bir tezahürüdür. Bu arada bir yüzyıl süren Haçlı seferlerini ve daha sonra ortaya çıkan coğrafi keşifleri de bu sebeplere bağlayabiliriz. Bu grup ve ordu hâlinde gerçekleşen seyahat, istila veya keşiflerin dışında İbn-i Batuta başta olmak üzere daha birçok meşhur seyyah dünyayı adım adım gezmiştir. İşte bu gezginlerden birisi de burada kısaca hayat hikâyesi ve gezdiği yerler hakkında bilgi vereceğimiz meşhur seyyahımız Evliya Çelebi'dir. Fakat onun seyahat hikâyesi oldukça farklıdır. Gelin ilk önce onun seyahate başlama hikâyesi ile devam edelim.

Rivayet odur ki seyyahımız rüyasında Muharrem ayının Aşure gecesi İstanbul'da Yemiş İskelesi civarında Ahî Çelebi Camii'ndedir. Vakit, sabah namazı vaktidir. Camide muazzam bir cemaat vardır. Evliyâ Çelebi, Peygamber Efendimiz Hz. Muhammet Mustafa(SAV)'yı kalabalığın en ön sıralarında görür. Peygamberimizin yanında dört halifesi ve ashâb-1 kirâm-1 da bulunmaktadır. Evliyâ Çelebi bu fırsatı kaçırmak istemez. Tam bu sırada araya giren Sa'd-1 Vakkas Hazretleri'nin telkinleri ile de tüm cesaretini toplar ve bin bir zahmetle peygamber efendimizin huzur-1 şeriflerine yaklaşır. Evliyâ Çelebi herkesin söylemek isteyip de dudağından bir türlü dökülemeyen "Şefaat yâ Resulallah" diyeceğine, "Seyahat yâ Resulallah" deyiverir. ${ }^{1}$ Evliyâ Çelebi Allah'ın sevgili bir kulu olmalı ki onun bu arzu ve isteği yerine ulaşır ve yetmiş bir yaşına kadar

\footnotetext{
1 Robert Dankoff, Seyit Ali Kahraman, Yücel Dağlı, Evliyâ Çelebi Seyahatnâmesi, Yapı Kredi Yayınları, 2006, C. I, s. 12. (Bundan sonra Seyahatnâme şeklinde zikredilecektir.)
} 
sürecek seyahati de başlamış olur. Evliyâ Çelebi bu yüksek ve kutsi görevi aldıktan sonra yollara düşer. Binlerce kilometre yol, yüzlerce memleket gezerek asrımızın en gizemli ve meşhur seyyahlarından birisi hâline gelir. Evliyâ Çelebi aldığı izn-i Resulallah ile ilk önce İstanbul'u, daha sonra tüm Osmanlı coğrafyasını ve komşularını gezer.

Evliyâ yetmiş bir y1llık ömrüne yaklaşık yirmi beş milyon km yol, 257 şehir ve birçok ülke sığdırmayı başarmıştır. Onun gezdiği yerlerin birçoğu o gün bir devletin sınırlarını teşkil etse de bugün hepsi müstakil birer devlet hâline gelmiştir. Gezdiği başlıca yerler arasında Anadolu, Suriye, Rumeli, Macaristan, Avusturya, Polonya, Almanya, Bosna-Hersek, Hollanda, Kırım, İran, Irak, Misır, Hebeşistan, Sudan ve Girit gelmektedir. Yaklaşık elli yıl boyunca Osmanlı coğrafyasını ve komşu ülkeleri karış karış gezmiştir.

Gelin isterseniz biraz tarih dersi işleyelim. Evliya Çelebi'nin gezdiği coğrafyada bugün yaklaşık yetmiş devlet bulunmaktadır. Birleşmiş Milletler'e üye olan devlet sayısının iki yüz üç olduğunu düşündüğümüz zaman Evliya Çelebi'nin gezmiş olduğu coğrafyanın büyüklüğünü, vermiş olduğu bilgilerin önem ve değerini daha iyi anlamış oluruz. Bu rakamlara günümüz seyyahları ulaşabilseler de Evliyâ'nın bize verdiği sır dolu bilgileri vermeleri biraz zor görünmektedir. Çünkü Evliyâ Çelebi'nin eserini okuyan bir kimse muhakkak aradığını bulabilmektedir. Her araştırmacı bilhassa edebiyat ve tarih üzerine çalışanlar yaptığı araştırmalar ile ilgili olarak acaba bu konuda Evliyâ Çelebi ne demiş diyerek yaptığı çalışma ile ilgili onun eserine bakma ihtiyacı duymaktadır. Herhangi bir araştırmanıza mehaz oluşturması veya merak ettiğiniz bir konu için onun seyahatnamesini incelediğiniz zaman muhakkak bir şeyler bulabilirsiniz. Onun verdiği bilgileri zaman zaman abartılı, zaman zaman bilimsel bulabilir, zaman zaman da tebessümle karşılayabilirsiniz. Bazen "Bu da olmaz." dediğiniz çok olmuştur. Ama yine de o bilgiyi zikretmeden geçemezsiniz. Bilhassa anlattığ1 olaylar yol ve yolcu hikâyeleri onun eserine ayrı bir güzellik katmıştır. Eserinde gördüklerini, yaşadıklarını, duyduklarını hatta hissettiklerini çok farklı bir üslup ile aktarmıştır. Burada bir yol ve yolcu hikayesi de ben zikretmek istiyorum:

Tarih boyunca yollar, yolcular ve kervanlar hep önemini korumuştur. Hatta kervanlar kültürlerarası iletişimin en önemli aktörlerinden birisi olmuştur. Burada sizlere Ulu Hakan II. Abdülhamit Han'ın en büyük projelerinden birisi olan Bağdat Demiryolları' nın yapımı sırasında yaşandığı rivayet edilen bir yol ve yolcu hikâyesini nakletmek istiyorum. Bağdat Demiryolları'nın yapımına başlandıktan sonra hat güzergâhında yaşayan köylüler biraz tedirgin biraz da meraklı gözler ile çalışan işçileri bazen izlemişler, bazen hanelerinde misafir etmişler bazen de bir bardak ayran ikram ederek onlarla koyu bir sohbet etmişlerdir. Bu sohbetlerden birisi sırasında yaşlı bir köylü:

“Evlat, siz buraya ne yapıyorsunuz?" diye soruvermiş... 
Yol yapımında çalışan genç mühendis, bu soru karşısında biraz düşündükten sonra, "Tren yolu yapıyoruz." dese köylü anlamayabilir... "Lokomotif..." dese hiç duymamıştır belki diye içinden geçirdi. "Buradan geçecek vasıtalar için ray döşüyoruz." dese rayı nereden bilecek diye düşünmeden edemedi. İhtiyar köylüye hem pratik hem de anlayacağı bir dille cevap vermek niyeti ile:

“Amca, sen buradan Bağdat'a kaç günde gidiyorsun?" diye sordu. Köylü bu soru karşısında mühendise dönerek;

"Evladım, buradan Bağdat otuz gün çeker." dedi. Bu cevap karşısında mühendis köylüye:

“İşte, biz öyle bir şey yapacağız ki sen buradan Bağdat'a bir günde varacaksın." diye cevap verdi. Bu cevap karşısında yaşlı bir o kadar da bilge adam, mühendise:

“Anladım evladım... İyi güzel ama ben geri kalan yirmi dokuz gün ne yapacağım?" diye cevap verdi. İşte Evliya Çelebi bu geri kalan yirmi dokuz günde tüm seyahat sırlarını bize edebiyatın tüm sanatlarını kullanarak aktarmıştır. İşte bu açılardan bakıldığı zaman seyahatname çok önemlidir. Çünkü seyahatname aslında bir günün değil geri kalan yirmi dokuz günün sırrını ve hikâyesini içerisinde barındırmaktadır. Gelelim şimdi seyyahımızın hayat hikâyesine...

\section{Kısaca Hayat Hikâyesi...}

Evliyâ Çelebi 25 Mart 1611/10 Muharrem 1020 tarihinde İstanbul Unkapanı'nda dünyaya gelmiştir. $\mathrm{O}$, İstanbul doğumlu olmasına rağmen aslen Kütahyalıdır. Evliyâ Çelebi'nin ataları İstanbul'un fethi sonrası bu şehre yerleşmişlerdir. Evliyâ Çelebi önce Sibyan Mektebinde daha sonra Unkapanı'nda bulunan Hamid Paşa Medresesinde yedi yıl iyi bir eğitim görmüştür. Aynı zamanda Dârü'l Kurraya da devam ederek Kuran-1 Kerim'i hıfz etmiştir. Daha sonra Enderun Mektebine de kabul edilen Evliyâ Çelebi burada dört yil hem eğitim almış hem de devlet terbiyesi kazanmıştır. Evliyâ Çelebi'nin bu anlamda diplomatik kişiliğini de unutmamak gerekir. Evliyâ Çelebi hat, musiki, nahiv ve tecvid gibi devrin gerekli tüm ilimlerini tahsil etti. Almış olduğu bu eğitimin izlerini eserine de yansıtmıştır. Evliyâ Çelebi aynı zamanda oldukça zeki, kabiliyetli ve hazırcevap bir karaktere sahiptir. Ayrıca yetişmiş olduğu çevre, eğitimi üzerinde olumlu bir etki yapmıştır. Bunun dışında yetişmiş olduğu çevre onu yaşından daha olgun, bilgili, görgülü, tedbirli, oturup kalkmasını bilen, meclis adabı ve söz söyleme sanatlarının inceliklerine vakıf, hiçbir sözün altında kalmayan, herkese yetiştirecek sözü olan, samimi, kibar, hassas ve dengeleri iyi 
kurabilen, bir bakışta olanı biteni kavrayıp ne yapılması gerektiğini kestiren ve en önemlisi espritüel bir kişiliğe sahip biri yapmıştır².

Evliyâ Çelebi bir seyyah olmanın ötesinde çok iyi bir gözlemcidir. O aynı zamanda "tarihçi, halkbilimci, müzisyen, ressam, haritacı, dilbilimci, zanaatkâr, mimar, savaşçı ve gurme" dir. ${ }^{3}$ Evliyâ Çelebi'nin en önemli özelliklerinden birisi cana yakın bir kişiliğe sahip olmasıdır. Yani tam bir insan dostudur. Evliyâ

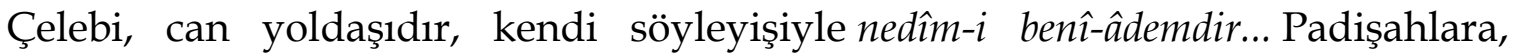
vezirlere, paşalara musahiplik yapmıştır. Sohbet ehlidir. Bilgisiyle, tatlı diliyle, nükteli konuşmasıyla, hazırcevaplığıyla, güzel sesiyle bir musahipte bulunması gereken bütün özelliklerle donanmıştır. Her mecliste aranan bir kişidir Evliyâ Çelebi... Kimi zaman Kur'an tilavet ederek, ilahiler söyleyerek; kimi zaman şarkılar terennüm ederek, şiirler okuyarak; kimi zaman fıkralar anlatarak, şakalar yaparak bulunduğu ortamı canlandırmıştır ${ }^{4}$.

Evliyâ Çelebi yapmış olduğu seyahatlerinde devlet ve devlet adamlarından çok büyük destekler de görmüştür. Seyahatlerinin birçoğunu görevli olarak gittiği zaman gerçekleştirmiştir. Zaman zaman da devletin özel bir elçisi gibi görev yapmıştır. Bu durum kaçınılmazdır. Çünkü aile çevresinin devlet ile olan bağları çok güçlüdür. Babası Derviş Mehmed Zillî sarayda kuyumcu başıdır. Kanuni Sultan Süleyman'in son dönemlerinden itibaren devleti ile sik1 münasebetleri vardır. Amcası Melek Ahmed Paşa dönemin en meşhur devlet adamlarından birisidir.

\begin{abstract}
“Hayatını seyahate vakfeden Evliyâ Çelebi, seyahatlerine yardımcı olması için zaman zaman mektup götürüp getirmek, köyleri tahrir etmek, vergi toplamak gibi görevleri kabul etmiştir. Bazen elçi kafilelerine katılarak daha emniyetli bir yolculuk yapma fırsatını değerlendirmiştir. Ailesinin zengin olması, uzun seyahatleri için gerekli kaynağı teminde kolaylık sağlamış olmalıdır. Nitekim seyahatlerinde köleleri, uşakları veya dostları yanında bulunurdu. Yerine getirdiği hizmetler karşılığında aldığı atıyyeler, seferlerde payına düşen ganimetler ve satışlardan elde ettiği kârlar da ona yeni gelirler sağlıyordu. Bazı seyahatlerinde ise katıldığı heyetler sayesinde aşırı masrafı olmuyordu." ${ }^{5}$
\end{abstract}

\title{
Bir Tarihçi Olarak Evliyâ Çelebi...
}

Onun eseri XVII. yüzyıl Osmanlı dünyasını en iyi anlatan eserlerden birisidir. Zaman zaman abartılı ve inanılması güç bilgiler verse de günümüzde

\footnotetext{
${ }^{2}$ Nurettin Gemici, “Evliyâ Çelebi'nin Dinî Referanslarının Sözlü Kaynakları”, Evliyâ Çelebi'nin Sözlü Kaynakları, Unesco Türkiye Milli Komisyonu Yayınları, İstanbul, 2013, s. 46.

3 Mücteba İlgürel, "Evliyâ Çelebi", TDVİA, C. 11, İstanbul, 1995, s. 529; Ülkü Çelik Şavk, Sorularla Evliyâ Çelebi, Hacettepe Üniversitesi Türkiyat Araştırmaları Enstitüsü Yayınları, Ankara, 2011, s. 34-50.

4 Şükrü Halûk Akalın, "Seyahatnâme'den Evliyâ Çelebi'ye", Türk Dili Dil ve Edebiyat Dergisi, Mart, 2011, s. 214.

${ }_{5}$ İlgürel, a.g.m., s. 529.
} 
dahi zevkle okunmaktadır. Bunun yanında resmî kayıtlara geçmeyen ve dönemin tarihçileri tarafından kaleme alınmamış birçok konuyu eserinde zikretmiştir. Yani Evliyâ Çelebi dönemin birçok olayına tanıklık etmiştir. Bu özelliğinden dolayı çok önemli bir tarihî kaynaktır. Osmanlı Devleti'nin idari taksimatı hakkında çok tafsilatlı bilgiler aktarır'. Evliyâ Çelebi'nin eseri iyi bir tarihî kaynak olduğu gibi Türk edebiyatının en güzel örneklerindendir.

Evliyâ Çelebi'nin verdiği bilgilerin tarihî anlamda önemi ve değeri tartışmasızdır. Gerçek anlamda sosyal bir tarihçidir. Olayları anlatırken her yönü ile aktarmasını bilmiştir. Geçmiş olayları anlatırken önemli kaynaklara atıflar da yapmıştır. Eserinde tarihî olayları, resmî tarihçilikten uzak bazen samimi bazen de abartılı ve inanılması güç şekilde aktarmıştır. Aslında mübalağa sanatını en güzel şekilde kullanmıştır. Yani Evliyâ Çelebi'nin anlattıkları abartı ve palavra değildir. Onun eserindeki bilgiler gerçek ve doğrudur. Sadece bilgilerin analiz ve tahlile ihtiyacı vardır. Ayrıca aktardığı bilgilerde onun gözlem ve hayal gücünü, olaylara bakış açısını, üslubunu görebilirsiniz. Olağanüstü birtakım olayların yer aldığı bölümler, aslında Evliyâ Çelebi'nin gittiği bölgedeki halkın kendisine anlattıklarından oluşmaktadır. Evliyâ Çelebi bu durumlarda darbımeseldir, böyle anlatırlar ama ben görmedim diyerek açılama getirir. Örneğin, herkesçe malum Erzurum'un soğuğu ile ilgili bölümde Evliyâ Çelebi şöyle yazmaktadır:

Erzurum'da kış öyle sert olur ki, insanların dilinde bir darbımeseldir ki bir dervişe sorarlar:

-Nereden gelirsin?

-Kar rahmetinden gelirim, der.

-O yer hangi diyardadır? derler.

-Soğuktan Ere-zulüm olan Erzurum'dur, der.

-Orada yaza rastladın mı hiç? derler. Derviş:

-Vallahi on bir ay yirmi dokuz gün orada kaldım, bütün halkı yaz gelir dediler amma ben görmedim, der.

Evliyâ Çelebi darbımeseli şöyle sürdürür: Hatta bir kere bir kedi bir damdan bir dama atlarken havada donup kalır. Sekiz aydan sonra bahar gelince, hava ısınınca, kedinin buzları çözülünce "Mırnav!" deyip yere düşer77.

Evliyâ Çelebi'nin Seyahatname'de anlattıklarının doğruluğu, yanlışlığı ya da abartılı olup olmadığı; tarih, coğrafya, mimarlık gibi çeşitli disiplinlerin denetimine açıktır. Bunun yanında, özellikle tarih, kültür ve edebiyat araştırmacıları için, seyahatnamenin asıl önemi belki de Evliyâ Çelebi'nin

${ }^{6}$ Seyahatnâme, s. 80.

${ }^{7}$ Akalın, s. 228. 
metnini "nerede", "neden" ve "nasıl" denkleminden uzaklaştırıp tarihî olayları, dinlediği hikâyeleri ve efsaneleri yerli yerinde ve bir sanat ustalığı ile kullanmasından kaynaklanmaktadır ${ }^{8}$.

\section{Evliyâ Çelebi Anadolu Yollarında...}

Evliyâ Çelebi ilk seyahatine 1640 yılında başlar. İlk seyahatine çıtı̆̆ı zaman 29 yaşındadır ve güzergâh Bursa'dır. Otuz beş gün süren bu seyahat sonrası tekrar İstanbul'a döner. İkinci seyahati ise İzmit ve çevresinedir. Evliyâ Çelebi bir kere yollara düşmüştür. Onu bundan sonra kimse durduramayacaktır. Yani olmuştur bizim Ahi(Bir rivayete göre ismi Ahi'dir) Çelebi şimdi bir Evliyâ... Evliyâa kelimesi Arapça "velî, keramet sahibi, ermiş, eren” sözünün çoğuludur. Bu kelime aynı zamanda "tecrübe" ile de yakından ilgilidir. Evliyâ olabilmek için deneyim şarttır. Nitekim bizim kahramanımız da seyahat konusundaki deneyiminden dolayı bu isimden daha güzel bir isimle adlandırılamazdı galiba9 .

Evliyâ Çelebi uzun soluklu ilk seyahatini Trabzon'a gerçekleştirir. Babasının himayesindeki devlet adamlarından Ketenci Ömer Paşa Trabzon'a vali olarak atandığ1 zaman Evliyâ onun maiyetindedir. Buradaki seyahati sırasında Azak kalesinin 1641 tarihinde geri alınmasına da şahitlik eder. Buradan Kırım Hanı'na misafir olur ve Karadeniz yolu ile İstanbul'a döner. Kırım'dan dönüşünde Karadeniz'de ilk defa bir kaza ile karşılaşır ve ölümden son anda kurtulur. Bu sebeple olmalı ki seyahatlerinin birçoğunu karayolu ile gerçekleştirmiştir. Deniz yolculuğundan nefret ettiğini eserinde birkaç kere zikretmiştir. Kırım dönüşü sonrası dört yıl İstanbul'da kalan Evliyâ Çelebi, 1645 yılında çıktığı seyahat sırasında Girit Savaşı'na katıldı ve tekrar İstanbul'a döndü ${ }^{10}$.

1647 yılında akrabası olan Defterdar Mehmed Paşa ile birlikte Erzurum'a gider. Aynı zamanda kendisine gümrük memurluğu görevi de tevdi edilmiştir. Bizim Evliyâ burada da boş durmaz. Nahcivan, Tiflis ve Tebriz seyahatlerini bu araya sıkıştırıverir. Bu seyahati sırasında babasının vefat haberi üzerine şehirlerin sultanı İstanbul'a döner... Bir süre İstanbul'da kaldıktan sonra güzergâh Şam'dır. Evliyâ Çelebi Murtaza Paşa'nın müezzinbaşısı olarak Şam’a gider. Bu görevi sırasında da Suriye, Filistin ve Anadolu'nun doğusundaki birçok şehri de gezme fırsatını elde eder.

\section{Kırım ve Nogay Taraflarına Geçişi...}

Evliya Çelebi Karadeniz'in kuzeyi ile birlikte Kırım coğrafyasını da gezmiştir. Evliya Çelebi'den onun gezdiği ve gördüğü yerler hakkında birçok

\footnotetext{
8 Yeliz Özay, "Hikâye Anlatıcı Olarak Evliyâ Çelebi ve Seyahatnamesinin Sözlü Niteliği”, Evliyâ Çelebi'nin Sözlü Kaynakları, UNESCO Türkiye Milli Komisyonu, Ankara 2012, s. 124.

${ }^{9}$ Firdevs Çetin, “İki Osmanlı Tipolojisinin Mukayesesi: Pirî “Reis” ile Evliyâ "Çelebi'nin Tarihi ve Fikri Serüveni", Çanakkale Araştırmaları Türk Yıllığı, S. 14, Bahar, 2013, s. 6.

${ }^{10}$ İlgürel, a.g.e., s. 530.
} 
bilgi öğrendiğimiz gibi, Nogayların yaşayışları, kültürleri ve siyasi yapıları hakkında bilgiler öğrenmekteyiz. Evliya Çelebi'nin Nogayların gündelik hayatında nasıl beslendiklerine dair verdiği örnekler dikkat çekicidir:

“...Ta'âmları yine talkan ve kurud ve yazma ve lahşa şorbası [ve] at eti ve at yelesi ve at kazısı, ya'nî at egeği kemikleri basdırması ve darı ekmeği yerler. El-hâsıl yedikleri darı, geydikleri deri, evleri saz, kendileri nâ-sâz kavimdirler. Asla buğday ekmeği yemezler ve su içmezler. Hemân boza ve maksima bozası içerler. Bu maksima bozası keyif vermeyüp ulemâ-yı Nogay içer, keskin bozaların yiğitleri içer..." Yine "...bu ulemâların izn-i şerîfleriyle cümle kavm-i Tatar at eti yerler..." ve "...Ol zamândan berü Tatar kavmi mâbeyninde birbirlerine ta'zîmen araba tekerleğiyle pişmiş koyun kebâbı yedirüp birkaç tostağan boza, ya'nî kulplu kadeh bozayı içirirler..."11

İsterseniz gelin biz de Kırım hakkındaki bilgilerimizi bir tazeleyelim. Kırım hem coğrafi konumu hem de havası ile fevkalade güzel bir yerdir. Hatta Rus Çarları zaman zaman buraya dinlenmek için gelmişlerdir. Karadeniz'in kuzeyinde ve stratejik bir konumda yer alan Kırım, tarihin her döneminde önemini korumuştur. Bu özelliğinden dolayı da ilkçağlardan günümüze kadar birçok kavme, topluluğa ve millete ev sahipliği yapmıştır. Türklerin Doğu'dan Batı'ya göçleri sırasında da bu yolu kullandıkları ve buralara yerleştikleri tarihî bir gerçektir. Tatar Türklerinin Kırım'a yerleşmeye başlaması ise XIII. yüzyılın başlarına tekabül eder. Kırım'ın sahil kesiminde oturanlara TAT, iç kesimlerde oturanlara ise TATAR denilmektedir. Kırım, 1237 yılında da Altın Orda hükümdarı Batu Han tarafından istila edildi. Kırım XIII. yüzyılın ortalarına doğru şehirde yaşayan batılı tüccarlar, Ermeniler ve Rumlarla birlikte tamamen bir Türk yurdu hâline gelmiştir. Yüzyılın ikinci yarısından itibaren de Kırım'a Selçuklu Türkleri yerleşmeye başlamıştır. Kırım'ın İslamlaşmaya başlaması da bu döneme rastlar. Kırımlılar bilhassa Özbek Han zamanında geniş kitleler hâlinde İslamiyet'i seçmiştir. Özbek Han, Kırım'da yaptırdı̆̆ı eserler ile de burada kalıcı olmasını başarmıştır. Kırım, Fatih Sultan Mehmet zamanında 1475 yılında Osmanlı egemenliğine girdi. Bu sayede Karadeniz bir Türk gölü hâline gelmiş oldu.

\section{Evliyâ Çelebi Evlâd-1 Fatihân Diyarlarında...}

Evliyâ Çelebi'nin en önemli seyahatlerinden birisi de Evlâd-1 Fatihân ${ }^{12}$ topraklarındaki seyahatidir. Onun kaleminden Sofya, Silistre, Rusçuk, Babadağı

\footnotetext{
${ }^{11}$ Alper Başer, Evliya Çelebi Seyahatnamesi'nde Nogaylar", Türk Dünyası İncelemeleri Dergisi, C. XI/2, Kış, 2011, s. 120.

${ }^{12}$ Evlâdı fatihan, Rumeli'nin fethinden sonra Balkanlarda yerleşmek üzere Anadolu MüslümanTürk halkından, aileleri ile birlikte gidenlere veya buraya gönderilenlere verilen addır. Bu uygulama Osmanlı Devleti'nin kuruluş döneminde buralardaki meşruiyeti ve tutunması açısından çok faydalı olmuştur. Rumeli'nin Türkleştirilmesi ve İslamlaştırılması maksadıyla Yörük ve Tatar Türkleri'nin bu bölgeye ilk defa ayak basmaları Sultan Yıldırım Bayezid zamanında başladı. Daha sonraları ise bu iskân siyaseti artarak devam etti ve ehemmiyet
} 
Özi ve daha birçok Balkan ve Avrupa kentleri hakkında bilgiler öğrenmekteyiz. Amcası Melek Ahmed Paşa Özi ve Rumeli valiliklerine atandığı zaman Evliyâ çelebi onun muhasebecisi ve müezinbaşısı görevi ile buradaki seyahatlerini gerçekleştirir. Evliyâ Çelebi Melek Ahmed Paşa'nın yanında 12 yıl kalmıştır. Onunla beraber 1650'den sonra Özi, Bosna, Rumeli, Van, Diyarbekir gibi yerleri gezmiştir.

Evliyâ Çelebi 1668 tarihinde İstanbul'a geri geldikten sonra aynı yıl içerisinde Edirne üzerinden Gümülcine, Selanik, Taselya ve Yunanistan'1 tamamen dolaştı. Tekrar 1671 yılında İstanbul'a döndü.

\section{Ve Güzergâh Viyana...}

Evliyâ Çelebi 1663 yılında Fazıl Ahmed Paşa'nın Avusturya üzerine düzenlediği sefere de katılır. Vasvar antlaşması sırasında Kara Mehmed Paşa, Viyana'ya elçilik görevi ile gittiği zaman Evliyâ Çelebi bu heyetin içerisindedir ${ }^{13}$. Bazı araştırmacıların bu seyahate şüphe ile yaklaşmasına rağmen o, Bohemya, İsveç ve Hollanda olmak üzere birçok ülkeyi görme fırsatını yakaladığından bahsetmektedir. Evliyâ Çelebi bu arada Macaristan'1 dolaştı, buradan tekrar Kırım'a geçti. 1668 senesinde İstanbul'a geri döndü.

Evliyâ Çelebi gittiği her yerde gördüğü ilginç olayları edebî sanatları da kullanarak en iyi şekilde aktarmasını bilmiştir. Viyana'da izlediği bir beyin ameliyatını eserinde zikreder. Bu olayı anlatırken de kullandığı betimlemeler ve edebî sanatlar oldukça ilginçtir.

“Kefereyi (kâfiri) dört ayaklı ipekli bir sedir üzerine yatırdılar. Başı Adana kabağı, burnu Mora patlıcanı gibi şişmişti. Hekimbaşı cümle kefereleri dışarı koğup mecruha (yaralıya) hemen safran gibi bir su içirip onu kendinden geçirdi. Hizmetkârı mecruhu kucağına alınca hekim adamın başının takke kenarı yerin etrafına tasma-kayış bağladı. Bir keskin ustura alıp, herifin alnının derisini iki kulaklarına kadar çizip sağ kulağı yanından deriyi biraz yüzünce kafa kemiği bembeyaz göründü. Cerrah hemen şakaktaki ek yerinden kafayı delip bir demir mengene sokup burmaya başladı. O burdukça herifin kellesinin

kazandı. (Yusuf Halaçoğlu, XIV-XVII, Yüzyıllarda Osmanlı Devlet Teşkilâtı ve Sosyal Yapı, TTKY, Ankara, 1995, s. 115.) Yükselme döneminde ve bilhassa Osmanlı Devleti'nin Avrupa üzerinde egemenlik kurduğu dönemlerde buraya yerleşen bu Müslüman-Türk grup çok rahat ve huzurlu bir yaşam sürmüştür. Fakat Rumeli'de yerleşen bu Yörük teşkilâtı zamanla dağılmaya yüz tuttu ve aralarındaki ahenk bozuldu. Dağınıklık ve disiplinsizlik ikinci Viyana kuşatmasından sonra kendini iyice gösterdi. Böylece halkın daha sıkı bir disiplin altına alınmasının gerekli olduğu ortaya çıtı. 1691 senesinde hatt-ı hümâyûn ile Yörük Türkleri, "evlâd-ı fâtihân" adı altında ve Rumeli'nin sağ, sol ve orta kolunda olmak üzere yeniden yazıldı ve zamanın ihtiyaçlarına göre teşkilâtın askerî ve iktisadî bünyesi az çok değiştirildi. (M. Tayyib Gökbilgin, Rumeli'de Yörükler, Tatarlar ve Evlâd-ı Fâtihân, Osman Yalçın Matbaası, İstanbul, 1957, s. 255; Ali Arslan, "Evlâd-1 Fâtihân Teşkilâtı'nın Kaldırılması", Balkanlar'da İslâm Medeniyeti Milletlerarası Sempozyumu Tebliğleri, 21-23 Nisan, 2000, İstanbul, 2002, s. 39)

${ }^{13}$ Çetin, a.g.m. s. 9. 
kapağı takke gibi kalkmaya başladı. Allah'ın emriyle kelle diş kenet yerlerinden açıldı. İçinde beyninin enseden tarafı göründü. Kellenin içi kulaklara kadar sulu kan ve sümük gibi bazı karışık şeylerle dolu olup beynin yanında kurşun dururdu. Meğer bu beş dirhem çakmaklı tüfek kurşunu imiş. Beynin zarı yanında kırmızı kana bulanmış durur. Hemen üstad cerrah hakire (bana), “Gör bak âdemoğlunun bir ekmek parçası için girdiği hali" dediğinde hakir dahi ileri varıp ağzıma ve burnuma mendili koyup mecruhun kellesinin içine nazar ettim. Garip insanın beyni kafa içinde güya tavuk yumurtasından yavrusu henüz çıkmış kuş gibi büzülmüş durur... Ama üzerinde bir kalın deriden zarfı yani zarı var. Cerrah başı ağzıma mendil koyup kafa içine baktığımdan dolayı bana, "Niçin ağzını ve burnunu kapayıp bakarsın" dedikte, hakir, "Belki bakarken aksırırım, öksürürüm. Herifin kellesinin içine rüzgâr girmesin diye kapadım" dedim. Cerrah, "Aferin. Sen bu ilimle meşgul olsan kâmil üstad cerrah olurdun" deyip aceleyle mecruh herifin beyni yanındaki kurşunu alıp sarı sünger gibi bir şeyle kurşunun durduğu yerdeki kanları, cerahatleri sildi, şarapla temizledi. Aceleyle kafayı yerine koydu, sonra tepesinden ve çenesi altından kayışlarla bağladı. O dakika hizmetkârı meydana bir kutu getirdi. Kutunun içinde iri karıncalar vardı... Bunlardan birini demir çifteyle (cımbız) alıp herifin kafa derisinin kesilen yerine yaklaştırınca aç karınca bir yerden iki deriyi birden 1sırdı. $\mathrm{O}$ an cerrah karıncayı belinden makasla kesti ve karıncanın başı iki deri kenarını ısıra kaldı... Öyle öyle ekleyip bir kulaktan bir kulağa seksen karıncayı 1sırtıp kesti. Sonra yarayı merhemledi. Bu hakir, yedi gün gelip gidip adamı seyreyledim. Sekizinci günde herif iyileşip biraz hareket etmeye başladı. On beşinci gün kralın huzuruna götürdüler."14.

\section{Evliyâ Çelebi Mekke yollarında...}

Evliyâ Çelebi 1668 yılında sekiz yıl gibi uzun bir süre süre uzak kaldığı İstanbul'a döner. Bu arada yukarıda da bahsettiğimiz gibi Balkanları gezer. Evliyâ Çelebi şairin ifadesiyle: "Bu şehr-i Sitanbûl ki bî-misl ü behâdır. Bir sengine yekpâre Acem mülkü fedadır." Yani koskoca bir Acem mülküne bile değişilemeyecek değerdeki şehirlerin sultanı İstanbul'da çok fazla kalmaz/kalamaz. Çünkü o, bir kere seyahat etmekteki sırrı kavramıştır.

Evliyâ Çelebi hem hac farizasını yerine getirmek hem de Arap coğrafyasını gezmek için tekrar 1671 tarihinde Anadolu'ya geçer. Bu konuda Evliyâ Çelebi eserinde Kadir gecesinde Eyüp Sultan Hazretleri'ni ziyaret ettikten sonra o gece rüyasında babası ve hocasını görür. Onlar Evliyâ Çelebi'ye hac etmesi yönünde tavsiyede bulunurlar. İşte Evliyâ Çelebi bu rüya üzerine üç arkadaşı ve yanındaki sekiz kölesi ile birlikte yeniden yollara düşmüştür. Diğer seyahatleri gibi seyyahımızın bu yolculuğu da bizleri şaşırtmaktadır. Çünkü o, Afyon'a kadar hac güzergâhını takip eder. Fakat buradan Uşak, Simav, Kula, Alaşehir, Akhisar, Manisa, Menemen, İzmir, Çeşme, Sakız Adası, Sivrihisar, Bodrum, Tire, Nazilli, Denizli, Muğla hatta Kıbrıs olmak üzere Ege kıyıları ve Ege bölgesini tamamen gezer. Akdeniz bölgesindeki adaları da gezdikten sonra Isparta, Elmalı, Antalya, Alanya, Adana, Misis, Ermenek, Silifke, Maraş ve Antep üzerinden

${ }_{14}$ Ülkü Çelik Şavk, Sorularla Evliyâ Çelebi, Hacettepe Üniversitesi Türkiyat Araştırmaları Enstitüsü Yayınları, Ankara, 2011, s. 17. 
Halep'e geçer. Evliyâ Çelebi çok meşakkatli ve sıkıntılı bir yolculuk ile Anadolu'da birçok şehri de gezdikten sonra Şam'da bir hac kafilesine dâhil olur $^{15}$. Evliya Çelebi aslında tüm seyahatlerini bir kervan veya yolcu kafilesi ile gerçekleştirmiştir. Çünkü o günün şartlarında bir kimsenin tek başına seyahat etmesi çok güvenli değildi. Bunun için de diğer seyahatlerinde olduğu gibi Evliya Çelebi Mekke yolculuğunda da bir hac kervanına dâhil olmuştur.

Hac farizasını yerine getiren Evliyâ Çelebi Mısır hac kafilesi ile birlikte Kahire'ye geçer. Nil'in hayat verdiği Mısır'ı gezer. Evliyâ Çelebi Mısır tarihini uzun uzun anlatırken de Nil hakkında çok ilginç bilgiler aktarır ve Nil'in özelliklerini çok güzel tasvir eder. Sudan ve Habeşistan'ı da gezmeyi ve görmeyi ihmal etmez. Evliyâ Çelebi nerdeyse eserinin bir cildini hac yolculuğuna ayırmıştır.

\section{Yollarda geçen bir ömür...}

Evliyâ Çelebi'nin sırlarla dolu yolculuğu gibi ölüm tarihi ve yeri de bugün bir sırdır. Fakat Evliyâ Çelebi'nin tartışmalı da olsa 1684 sonlarına kadar yaşadığı tahmin edilmektedir. Evliyâ Çelebi eserini ise Mısır'da tamamladığını zikretmektedir. Çünkü o muhteşem eserinde:

“... lâ nihâye hamd [ü] senâ olsun kim Cenâb-1 Bârî yârî kılup Mısır Kâhire-i nâdiretü'lasrda bu evrâk-1 perîşânımız hırka-i dervîşân-1 nemedpûşân gibi elvân elvân olup itmâm buldu"16 ifadelerini kullanır.

Sonuç olarak şunu söyleyebiliriz ki; Evliyâ Çelebi hayatı boyunca binlerce kilometre yol, yüzlerce şehir, onlarca ülke -hatta bugünkü ülke sınırlarını düşündüğümüz zaman yüze yakın ülke- gezerek o günkü yaşam şartlarını, devletin siyasi, askerî, ekonomik ve sosyal durumu ile ilgili bilgileri günümüze aktarmıştır. Aktardığı bilgilerin önemi, bazı olaylara bizzat şahitlik etmesinden bazı olayları da dinlediği kişilerin dilinden aktarmış olmasından kaynaklanmaktadır. Eserinde tarih, edebiyat, coğrafya gibi birçok ilim ile ilgili çok detaylı bilgiler bulabilirsiniz.

15 Nurettin Gemici, “Evliyâ Çelebi'nin Hac Ziyareti ve Seyahatnamenin Hac Bölümünün Kaynakları", Diyanet İlmi Dergi, C. 45, S. 3, Eylül, 2009, s. 85.

${ }^{16}$ Çetin, a.g.e., s. 13. 


\section{KAYNAKÇA}

AKALIN, Şükrü Halûk, "Seyahatnameden Evliyâ Çelebi'ye", Türk Dili Dil ve Edebiyat Dergisi, Mart, 2011.

ARSLAN, Ali, "Evlâd-1 Fâtihân Teşkilâtı'nın Kaldırılması", Balkanlar'da İslâm Medeniyeti Milletlerarası Sempozyumu Tebliğleri, 21-23 Nisan, 2000, İstanbul, 2002.

BAŞER, Alper, Evliya Çelebi Seyahatnamesinde Nogaylar", Türk Dünyası İncelemeleri Dergisi, C. XI/2, Kış, 2011.

ÇETIN, Firdevs, “İki Osmanlı Tipolojisinin Mukayesesi: Pirî "Reis" ile Evliyâ "Çelebi'nin Tarihi ve Fikri Serüveni”, Çanakkale Araştırmaları Türk Yıllı̆̆̆, S. 14, Bahar, 2013.

DANKOFF, Robert, Seyit Ali Kahraman, Yücel Dağlı, Evliyâ Çelebi Seyahatnâmesi, Yapı Kredi Yayınları, İstanbul, 2006.

GEMICİ, Nurettin, "Evliyâ Çelebi'nin Dinî Referanslarının Sözlü Kaynakları", Evliyâ Çelebi'nin Sözlü Kaynakları, Unesco Türkiye Milli Komisyonu Yayınları, İstanbul, 2013.

GEMICI, Nurettin, “Evliyâ Çelebi'nin Hac Ziyareti ve Seyahatnamenin Hac Bölümünün Kaynakları", Diyanet İlmi Dergi, C. 45, S. 3, Eylül, 2009.

GÖKBİLGIN, M. Tayyib, Rumeli'de Yörükler, Tatarlar ve Evlâd-ı Fâtihân, Osman Yalçın Matbaası, İstanbul, 1957.

HALAÇOĞLU, Yusuf, XIV-XVII, Yüzyıllarda Osmanlı Devlet Teşkilâtı ve Sosyal Yapı, TTKY, Ankara, 1995.

İLGÜREL, Mücteba, “Evliyâ Çelebi”, TDVİA, C. 11, İstanbul, 1995.

ÖZAY, Yeliz, "Hikâye Anlatıcı Olarak Evliyâ Çelebi ve Seyahatnamesinin Sözlü Niteliği", Evliyâ Çelebi'nin Sözlü Kaynakları, UNESCO Türkiye Milli Komisyonu, Ankara, 2012.

ŞAVK, Ülkü Çelik, Sorularla Evliyâ Çelebi, Hacettepe Üniversitesi Türkiyat Araştırmaları Enstitüsü Yayınları, Ankara, 2011. 